\title{
Assessing acrylamide content in sterilized Californian-style black table olives using HPLC-MS-QQQ and a potentiometric electronic tongue
}

\author{
Daniel Martín-Vertedor ${ }^{\mathrm{a}, \mathrm{b}, *}$, Nuno Rodrigues ${ }^{\mathrm{c}}$, Ítala M.G. Marx ${ }^{\mathrm{c}, \mathrm{d}}$, Luís G. Dias ${ }^{\mathrm{c}}$, \\ Ana C.A. Veloso ${ }^{\mathrm{e}, \mathrm{f}}$, José Alberto Pereira ${ }^{\mathrm{c}}$, António M. Peres ${ }^{\mathrm{c}}$ \\ ${ }^{a}$ Technological Institute of Food and Agriculture (CICYTEX-INTAEX). Junta of Extremadura, Avda. Adolfo Suárez S/n, 06007, Badajoz, Spain \\ ${ }^{\mathrm{b}}$ Research Institute of Agricultural Resources (INURA), Avda. de la Investigación S/n, Campus Universitario, 06071, Badajoz, Spain \\ ${ }^{\mathrm{c}}$ Centro de Investigação de Montanha (CIMO), Instituto Politécnico de Bragança, Campus de Santa Apolónia, 5300-253, Bragança, Portugal \\ ${ }^{\mathrm{d}}$ LAQV-REQUIMTE, Faculdade de Farmácia da Universidade do Porto, Rua de Jorge Viterbo Ferreira n.o 228, 4050-313, Porto, Portugal \\ e Instituto Politécnico de Coimbra, ISEC, DEQB, Rua Pedro Nunes, Quinta da Nora, 3030-199, Coimbra, Portugal \\ ${ }^{\mathrm{f}}$ CEB - Centre of Biological Engineering, University of Minho, Campus de Gualtar, 4710-057, Braga, Portugal
}

\section{A R T I C L E I N F O}

\section{Keywords:}

Table olives cultivars

Thermal treatments

Acrylamide

Electronic tongue

Chemometrics

\begin{abstract}
A B S T R A C T
The study aimed to evaluate the effects of olive cultivar (cvs. Manzanilla Cacereña and Hojiblanca) and the sterilization intensity/time-period $\left(\mathrm{F}_{0}\right.$ of $10-25 \mathrm{~min}$ at $\left.121 \pm 3{ }^{\circ} \mathrm{C}\right)$ on the formation of acrylamide in table olives and brine. Olive cultivar and thermal sterilization had a significant impact on the amount of acrylamide produced (varying from $228 \pm 94$ to $286 \pm 110$ and $336 \pm 126$ to $373 \pm 159 \mathrm{ng} \mathrm{g}^{-1}$, for table olives and brine, respectively, determined by HPLC-MS-QQQ). Moreover, for both cultivars, linear positive relationships $\left(0.931 \leq R^{2} \leq 0.994\right)$ were found between the acrylamide concentration in olives and respective brine solutions, allowing to foresee a non-destructive indirect methodology for quantifying acrylamide in table olives. Finally, a potentiometric E-tongue was used to quantify acrylamide in both matrices. The lipid sensor membranes comprised on the sensor device showed potentiometric semi-logarithmic responses $\left(0.962 \leq R^{2} \leq 0.999\right)$ towards the acrylamide concentration for aqueous standard solutions, permitting the establishment of accurate multiple linear predictive models for the quantification of acrylamide in olives and brine solutions (repeated $K$ fold-CV: $0.97 \pm 0.03 \leq R^{2} \leq 0.99 \pm 0.01 ; 12 \pm 8 \leq R M S E \leq 28 \pm 14 \mathrm{ng} \mathrm{g}^{-1}$ ) for both olive cultivars. $E$ tongue could be used as non-destructive indirect detection method of acrylamide, based on the brine solution evaluation, and so, a complementary analytical tool to the conventional chromatographic analysis.
\end{abstract}

\section{Introduction}

Californian-style black table olives are produced by subjecting olives to several lye treatments in order to eliminate the bitterness and to obtain olives with black color. Black table olives are placed in cans with a brine solution being then subjected to a thermal sterilization treatment since olives are not microbiologically stable (Martín-Vertedor et al., 2020). However, the high temperatures (equal or greater than $121^{\circ} \mathrm{C}$ ) are responsible for the occurrence of multiple complex chemical reactions, such as the Maillard reaction, being involved free asparagine and reducing sugars, which promoted the acrylamide formation pathway (Pérez-Nevado, Cabrera-Bañegil, Repilado, Martillanes, \& Martín-Vertedor, 2018). For example, Tang et al. (2016) have verified that acrylamide synthesis is promoted when olives are subjected to temperatures above $120^{\circ} \mathrm{C}$. Acrylamide is highly toxic and carcinogenic (Charoenprasert \& Mitchell, 2014; IARC, 1994; Martín-Vertedor et al., 2020; Tang et al., 2016). Indeed, the negative health effects related to the intake of this toxic compound due to its presence in different food matrices has been recently highlighted (EFSA, 2015; Lodolini et al., 2019). In other table olives elaboration processes, such as the Spanishstyle or Greek elaboration processes, in which a final thermal pasteurization is only applied for preservation, acrylamide is not synthesized (Lodolini et al., 2019; Montaño, Casado, \& Carle, 2015). The intensity of the sterilization process applied during the production of Californianstyle black table olives depends on the production practices implemented by each industry, and so, a wide concentration range of acrylamide has been found, ranging from 31.5 to $1044.0 \mathrm{ng} \mathrm{g}^{-1}$ in olives and from 59.2 to $1740.0 \mathrm{ng} \mathrm{g}^{-1}$ in the brine solutions (Casado \&

\footnotetext{
${ }^{*}$ Corresponding author. Technological Institute of Food and Agriculture (CICYTEX-INTAEX). Junta of Extremadura, Avda. Adolfo Suárez s/n, 06007, Badajoz, Spain.

E-mail addresses: daniel.martin@juntaex.es (D. Martín-Vertedor), nunorodrigues@ipb.pt (N. Rodrigues), itala.marx@ipb.pt (Í.M.G. Marx), ldias@ipb.pt (L.G. Dias), anaveloso@isec.pt (A.C.A. Veloso), jpereira@ipb.pt (J.A. Pereira), peres@ipb.pt (A.M. Peres).
} 
Montaño, 2008; Pérez-Nevado et al., 2018). To minimize this potential health concern which is related to the application of the olives' thermal sterilization, the Spanish legal regulation (Ministerio de la Presidencia, 2001), which required a minimum value of thermal sterilization (i.e., a cumulative lethality $\mathrm{F}_{0} \geq 15 \mathrm{~min}$ ), was repealed and replaced by Ministerio de la Presidencia (2016), which does not require anymore the use of a minimum amount of heat to sterilize olives.

Nevertheless, the detection of acrylamide in table olives is still of utmost relevance for human safety reasons. Indeed, olives in brine are included in the list of foods for which acrylamide levels must be monitored by the authorities of the Member States of the European Union (EU) (Commission Recommendation (EU) 2019/1888, 2019). The most common analytical techniques for assessing acrylamide levels in Californian-style black table olives are gas chromatography with mass spectrometry (Casado \& Montaño, 2008; Crawford \& Wang, 2019) and liquid chromatography-mass spectrometry (Casado, Montaño, Spitzner, \& Carle, 2013; Martín-Vertedor et al., 2020; Pérez-Nevado et al., 2018). However, these techniques require sample pre-treatments namely, acrylamide extraction and extract purification, turning out into a time-consuming procedure. Besides, the chromatographic techniques, namely with mass detectors, not only require skilled techniques but also expensive equipment, which are far beyond the economic capability of small and medium table olives producers. Thus, from an industrial point of view, it would be important to have a fast, portable and userfriendly device for the direct quantification of acrylamide in the last step of the elaboration of Californian-style black table olives, which only required a minimum sample pre-treatment. In this context, voltametric biosensors and aptasensors have been developed and applied for detecting acrylamide in foods and other matrices (Asnaashari, Esmaeilzadeh Kenari, Farahmandfar, Taghdisi, \& Abnous, 2018;Asnaashari, Kenari, Farahmandfar, Abnous, \& Taghdisi, 2019; Mülazimoğlu, Sağir, Durmuş, \& Mülazimoğlu, 2017; Sani, Heng, Marugan, \& Rajab, 2018; Wulandari, Ivandini, Irkham, Saepudin, \& Einaga, 2019).

On the contrary, potentiometric sensor devices, namely electronic tongues (E-tongue), have not been used until now for detecting acrylamide in olives or other food matrices. Nevertheless, an E-tongue comprising lipid polymeric sensor membranes can theoretically detect acrylamide since an electrostatic interaction can be established between the lipid membranes and the amine group of acrylamide (Kostritskii, Kondinskaia, Nesterenko, \& Gurtovenko, 2016). For example, a potentiometric E-tongue coupled with multivariate statistical tools has been successfully applied for classifying table olives according to the commercial grade as well as for quantitatively assessing chemical and sensory attributes (positive and negative sensations) of table olives (Marx et al., 2017a; 2017b; 2017c). Thus, this study aims to evaluate the quantitative performance of a potentiometric E-tongue for assessing the acrylamide content of Californian-style black table olives (cvs. Manzanilla Cacereña and Hojiblanca) submitted to four different thermal treatments (10-25 min at $\left.121 \pm 3{ }^{\circ} \mathrm{C}\right)$, through the direct analysis of olive aqueous pastes as well as of the respective brine solutions.

\section{Material and methods}

\subsection{Table olives samples}

Hojiblanca and Manzanilla Cacereña olive cultivars were harvested at green maturation stage in 2018 olive crop season and stored in industrial tanks of 16,000 L of capacity. Olives were stored in triplicate in a table olive company located in the northwest of Extremadura (Spain). Table olives were processed according to the Californian-style black table olive (Martín-Vertedor et al., 2020). Briefly, olives were treated with $\mathrm{NaOH}$ to remove the bitter taste, being air bubbled continuously to oxidise the olives. After neutralisation with lactic acid and $\mathrm{CO}_{2}$, a ferrous gluconate solution $(0.15 \%, \mathrm{w} / \mathrm{v})$ was applied to fix the colour. Olives were then washed to remove any ferrous gluconate residual and then packed $(150 \mathrm{~g})$ in cans with a solution containing $2 \%$ of $\mathrm{NaCl}$ and $0.015 \%$ (10-40 ppm) of ferrous gluconate. Contrary to the Spanish or Greek table olives styles, during the elaboration process of the Californian-style black table olives no spontaneous fermentation occurred.

\subsection{Thermal sterilization treatments}

Cans were sterilized at $121 \pm 3{ }^{\circ} \mathrm{C}$ applying different thermal treatments combinations in order to give a reduction ratio in microorganisms taking into account their cumulative lethality (" $F_{0}$ value"). Two coupled Pt100 temperature sensors (Autoclave Load RTD, Type 69A, United Kingdom), were stuck, each one on an olive and placed in the center of two cylindrical cans $(6.7 \mathrm{~cm}$ of diameter and $10.2 \mathrm{~cm}$ of height). The sensors were connected to a computer, allowing to record the temperature profile inside the sealed cans during the processing time, ensuring that the desired heat penetration was attained. The $\mathrm{F}_{0}$ value was automatically calculated using the recorded heat penetration data (by integrating the time-temperature profile recorded by each sensor and for each treatment) and expressed as the equivalent treatment duration (in minutes) required to reduce initial microbial load, at a specified temperature, to a desired value, assuring the inactivation or the reduction of thermo-resistant spoilage bacterial spores (Tang et al., 2016). Thus, table olives from both olive cultivars were submitted to different thermal sterilization treatments allowing to achieve four different $F_{0}$ values, namely, $F_{0}=10 \mathrm{~min}(\mathrm{~T} 1), \mathrm{F}_{0}=15 \mathrm{~min}$ (T2), $\mathrm{F}_{0}=20 \mathrm{~min}(\mathrm{~T} 3)$ and $\mathrm{F}_{0}=25 \mathrm{~min}(\mathrm{~T} 4)$. All experiments were done in triplicate and the results based on the experimental data were expressed as mean values \pm standard deviation. During storage, cans were protected from light exposure and kept at room temperature until analysis.

\subsection{Reagents, solvents and standards}

Acrylamide $(>99 \%)$ was obtained from Fluka (Buchs SG, Switzerland) and 2,3,3-D3-acrylamide (98\%) from Cambridge Isotope Laboratories (Andover, MA, USA). Standard solutions of both compounds were prepared by dissolving them with Milli-Q water (Type I ultrapure water, resistivity of $\sim 18.2 \mathrm{M} \Omega \mathrm{cm}$ ). Methanol was analytical grade (Merck, Darmstadt, Germany). Isolute Multimode (300 mg, $6 \mathrm{~mL}$ ) and ENV + $(200 \mathrm{mg}, 3 \mathrm{~mL})$ were obtained from IST (Hengoed, MidGlamorgan, UK). Syringe filters $0.45 \mu \mathrm{m}$ of nylon and nitrocellulose were purchased from Tracer Tecnologías Analíticas (Madrid, Spain). Water used was purified with an Elix/Milli-Q water purification system (Millipore, Bedford, MA, USA). For the potentiometric assays, deionized water type II was used. The E-tongue (two cylindrical sensor arrays) comprised different lipid membranes containing a mixture of lipid additives (octadecylamine, oleyl alcohol, methyltrioctylammonium chloride and oleic acid; $\approx 3 \%$ ); plasticizers (bis(1-butylpentyl) adipate, dibutyl sebacate, 2-nitrophenyl-octylether, tris(2-ethylhexyl)phosphate and dioctyl phenylphosphonate; $\approx 65 \%$ ) and high molecular weight polyvinyl chloride (PVC; $\approx 32 \%$ ). All reagents were from Fluka (minimum purity $\geq 97 \%$ ).

\subsection{Acrylamide assessment by HPLC-MS-QQQ}

The method used for the detection of acrylamide was validated according to Fernández et al. (2020) which established the optimal extraction conditions related to the sensitivity, limits of detection and quantification, repeatability and recovery of HPLC-MS-QQQ method. To obtain a homogeneous paste to analyze, fresh Californian-style black table olives were crushed with a thermobeater until a homogeneous mixture. After, the olive pastes were stored in bottles at $-80{ }^{\circ} \mathrm{C}$. The acrylamide analysis was performed using the proper protocol previously described by Pérez-Nevado et al. (2018). Briefly, $2 \mathrm{~g}$ of table olives were stirred with $10 \mathrm{~mL}$ of distilled water, centrifuged and filtered, while the brine solution was only filtered. Both extracts obtained 
were subjected to solid-phase extraction using PCX (200 mg/3 mL) and PRP (60mg/3 mL) column cartridges (Telos, Kinesis, Australia). The extract was analysed by high-performance liquid chromatography-triple quadrupole mass spectrometry (HPLC-MS-QQQ). Then, $20 \mu \mathrm{L}$ of $250 \mathrm{ng} \mathrm{g}^{-1}$ of acrylamide (Sigma-Aldrich, CAS: 76-06-1, purity $\geq 99 \%$, Steinheim, Germany) was added to the sample (standard addition method), and it was re-analysed twice to calculate the recovery percentages.

\subsection{Electronic tongue assays}

\subsubsection{E-tongue device}

The E-tongue was home-made and included two cylindrical sensor arrays. As previously described (Marx et al., 2017a), each array had 20 lipid polymeric cross-sensitive membranes containing $3 \%$ of a lipid additive, $32 \%$ of a plasticizer and $65 \%$ of polyvinyl chloride. A multiplexer Agilent Data Acquisition Switch Unit (model 34970 A) and an Agilent BenchLink Data Logger software were used for registering the membranes signal profiles. The 40 potentiometric signals were recorded during $5 \mathrm{~min}$, and were the result of the electrostatic or hydrophobic interactions established between the membranes and the polar compounds (Kobayashi et al., 2010) found in the tables olives or in the brine solutions. $\mathrm{An} \mathrm{Ag} / \mathrm{AgCl}$ double-junction glass electrode (Crison, 5241) was used as the reference electrode. The E-tongue was stored at room temperature and immersed in a $\mathrm{HCl}$ cleaning solution $\left(0.01 \mathrm{~mol} \mathrm{~L}^{-1}\right)$. As in previous studies, the sensor codes included the letter $S$ for sensor identification, the array number (1: or 2 ) and the membrane number (1-20) (Marx et al., 2017a).

\subsubsection{E-tongue response towards acrylamide aqueous standard solutions}

To verify the capability of the E-tongue to detect and quantify acrylamide a series of preliminary assays were carried out using acrylamide aqueous standard solutions $(100 \mathrm{~mL})$. The E-tongue signal profiles were recorded for acrylamide standard solutions with concentrations of 2.5, 5.0, 10.0, 15.0 and $20.0 \mathrm{ng} \mathrm{g}^{-1}$. For each sensor comprised in the E-tongue device, a per excess estimative of the limit of detection (LOD) was set based on the semi-logarithmic calibration curves established between the sensor potential signals and the decimal logarithm of the acrylamide concentration (Nernstian type behavior). The LOD was assumed to be equal to the lowest concentration of the linear region. Intra-day and inter-day repeatability (i.e., the variation coefficient percentage, $\mathrm{CV} \%$ ) of the potential signals recorded by each E-tongue sensor were further evaluated by analyzing each standard solution $5 \times$ in the same day and $3 \times$ in two consecutive days.

\subsubsection{Table olives sample preparation and potentiometric analysis}

The lab-made E-tongue was used to gather potentiometric profiles of the table olives (cvs. Hojiblanca and Manzanilla Cacereña), produced according to the Californian-style black table olives. In total, for each matrix, $24+24$ samples were analysed (table olives and brine solutions) including six replicas for each of the four thermal treatments and for each cultivar. For table olives analysis, a fine grained aqueous olive paste was obtained using IKA T-18 Basic Ultra Turrax ${ }^{\circledast}$ Homogenizer equipment (using $25 \mathrm{~g}$ of olives without stone plus $75 \mathrm{~mL}$ of deionized water). For the analysis of the brine solutions and to keep a similarity to the olive assay, brines were diluted using deionized water $(25 \mathrm{~mL}$ of brine and $75 \mathrm{~mL}$ of deionized water, ensuring a similar proportion of that used for obtaining the olive aqueous paste). All assays were performed at the same time in the laboratoryat approximately $20{ }^{\circ} \mathrm{C}$ under agitation (VELP Scientifica magnetic stirrer). After the immersion of the E-tongue in each sample, 40 sensors signals were recorded after a 5-min stabilization period, monitored at each 10-s interval (Marx et al., 2017a). All assays were carried out in the same day ensuring that a negligible signal drift (Prata et al., 2018).

\subsection{Statistical analysis}

The statistical significance of the olive cultivar and of the thermal sterilization treatment on the acrylamide concentration of olives and brine was evaluated by a two-way ANOVA with interaction. When the interaction effect was not statistically significant or if a significant additive interaction was found, one-way ANOVA followed by the Tukey's multiple range test were further used. If a non-additive or disordinal significant effect was observed the analysis was performed based on the estimated marginal mean plots to discuss at which level the factors influenced the dependent variable under study (Field, 2009). Multiple linear regression (MLR) coupled with the simulated annealing (SA) algorithm were also used to identify the non-redundant $E$-tongue sensors that should be used to established MLR models for assessing the acrylamide concentrations of the table olives as well of their brine solutions, which were experimentally determined by HPLC-MS-QQQ. The quality of the E-tongue-SVM-SA models was evaluated using the coefficient of determination $\left(R^{2}\right)$ and the root-mean-square error (RMSE) for the LOO-CV and the repeated $K$-fold-CV procedures. Finally, the accuracy of the MLRM-SA-E-tongue models was compared against the analytical conventional techniques used for assessing the chemical and sensory data (Roig \& Thomas, 2003a; 2003b). The analysis was carried out with the Sub select (Cadima, Cerdeira, \& Minhoto, 2004) and MASS (Venables \& Ripley, 2002) packages of the open source statistical program R (version 2.15.1), at a 5\% significance level.

\section{Results and discussion}

\subsection{Effect of olive cultivar and thermal sterilization treatment on the acrylamide formation}

A two-way ANOVA (Table 1) showed that acrylamide content in table olives and brine solutions (determined by HPLC-MS-QQQ) were,

Table 1

Two-way ANOVA: influence of olive cultivar (cvs. Manzanilla Cacereña and Hojiblanca) and thermal sterilization treatments (T1-T4) on the acrylamide content of Californian-style black table olives and brine solutions after processing. Results are expressed as mean \pm SD of three sample replicates. Different small letters in the same column indicate significant statistical differences between cultivars or thermal treatments (Tukey's Test, $P$-value $<0.05$ ).

\begin{tabular}{|c|c|c|c|}
\hline \multirow[t]{2}{*}{ Factor } & \multirow[t]{2}{*}{ Levels } & \multicolumn{2}{|c|}{ Acrylamide content $\left(\mathrm{ng} \cdot \mathrm{g}^{-1}\right)$} \\
\hline & & Olives & Brine Solutions \\
\hline \multirow[t]{3}{*}{ Olive Cultivar } & cv. Manzanilla Cacereña & $228 \pm 94^{\mathrm{b}}$ & $336 \pm 126^{\mathrm{b}}$ \\
\hline & cv. Hojiblanca & $286 \pm 110^{\mathrm{a}}$ & $373 \pm 159^{\mathrm{a}}$ \\
\hline & $P$-value & $<0.0001$ & $<0.0001$ \\
\hline \multirow[t]{5}{*}{ Thermal Sterilization Treatment $\left(121 \pm 3{ }^{\circ} \mathrm{C}\right)$} & $\mathrm{T} 1\left(\mathrm{~F}_{0}=10 \mathrm{~min}\right)$ & $151 \pm 21^{d}$ & $198 \pm 16^{\mathrm{d}}$ \\
\hline & $\mathrm{T} 2\left(\mathrm{~F}_{0}=15 \mathrm{~min}\right)$ & $194 \pm 23^{c}$ & $260 \pm 7^{c}$ \\
\hline & $\mathrm{T} 3\left(\mathrm{~F}_{0}=20 \mathrm{~min}\right)$ & $270 \pm 37^{b}$ & $401 \pm 6^{\mathrm{b}}$ \\
\hline & $\mathrm{T} 4\left(\mathrm{~F}_{0}=25 \mathrm{~min}\right)$ & $414 \pm 41^{\mathrm{a}}$ & $559 \pm 58^{\mathrm{a}}$ \\
\hline & $P$ & $<0.0001$ & $<0.0001$ \\
\hline "Olive Cultivar" $\times$ “Thermal Sterilization Treatment" interaction & $P$ & $<0.0001$ & $<0.0001$ \\
\hline
\end{tabular}



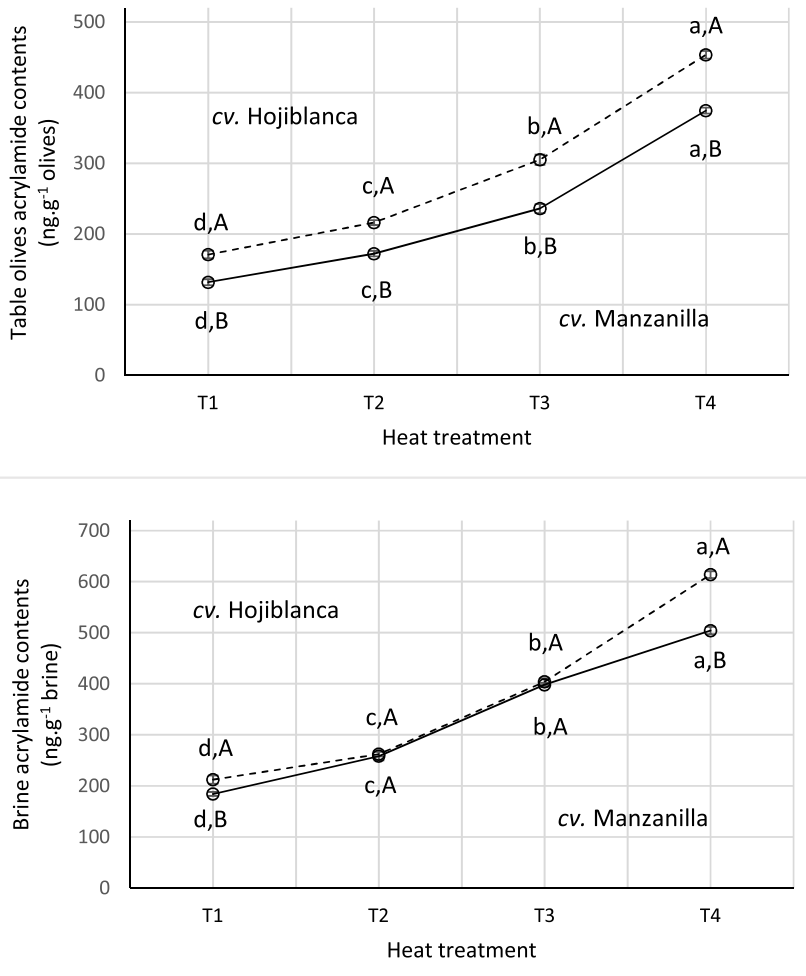

Fig. 1. Estimated marginal mean plots for acrylamide concentrations found by HPLC-MS-QQQ in Californian-style black olives and brine solutions (cvs. Manzanilla Cacereña and Hojiblanca), submitted to different thermal sterilization treatments (T1-T4). Results are expressed as mean \pm SD of three sample replicates. For the same cultivar, different lowercase letters mean a statistical significant difference between thermal treatment (one-way ANOVA followed by Tukey's test, $P<0.05$ ). For the same thermal treatment, different uppercase letters mean a statistical significant difference between olive cultivar (one-way ANOVA followed by Tukey's test, $P<0.05$ ).

from a statistical point of view, significantly influenced by the "olive cultivar" and the "thermal sterilization treatment" effects $(P \leq 0.05)$ being also found a significant interaction effect $(P \leq 0.05)$. Nevertheless, the interaction effect was additive (non-disordinal effect), as shown by the inexistence of crossing lines in Fig. 1, which allowed discussing each main effect individually either based on the Tukey's multi-comparison post-hoc test or by the inspection of the estimated marginal plots (Fig. 1). It should be remarked that, the magnitude of the standard deviations listed in Table 1, namely for the olive cultivar, are attributed to the high influence of the thermal sterilization treatment on the acrylamide content, leading to a wide range of concentrations depending on the applied treatment. On the other hand, Fig. 1 clearly shows that for each cultivar and thermal treatment, the data do not show a huge variability (small error bars), varying the CV\% of the determined acrylamide contents from 1.1 to $3.2 \%$ and $0.9-3.8 \%$ for the olive cultivar and sterilization treatment, respectively. Overall, the thermal sterilization treatments $\left(10-25 \mathrm{~min}\right.$ at $\left.121 \pm 3{ }^{\circ} \mathrm{C}\right)$ used during the production of the Californian-style black table olives were responsible for the acrylamide synthesis, which extent depended on the time-period of the heat treatment (Table 1). The acrylamide formation is a major health concern due to its known high toxicity. However, it is known that the different industrial thermal treatments applied in sterilization of olive cans for guaranteeing the inactivation or reduction of thermo-resistant spoilage bacterial spores, promote the synthesis of acrylamide. In fact, as reported by Pérez-Nevado et al. (2018), sterilized canned olives (e.g., Spanish and Portuguese Californian-style black ripe olives) showed different levels of acrylamide, mainly due to the different industrial thermal treatments, which intensity, temperature and time-period highly vary from industry to industry. Indeed, a linear correlation has been found between the $\mathrm{F}_{0}$ value and the acrylamide content in industrial oxidised black olives or in the respective brine solutions (Pérez-Nevado et al., 2018).

The results of the present study (Table 1 and Fig. 1) pointed out that, regardless the applied thermal treatment, olives and brine solutions from $c v$. Manzanilla Cacereña had a significant lower acrylamide level than $c v$. Hojiblanca $(P \leq 0.05)$. The content of this toxic substance is probably related to the olive cultivar since both cultivars were subjected to the same elaboration process as Californian-style, and despite this, the synthesis of acrylamide differed according to the studied cultivar. Some authors (Lodolini et al., 2019; Montaño et al., 2015; PérezNevado et al., 2018) have reported clear differences in the acrylamide content for different olive cultivars elaborated as Californian-style black table olives, being observed that $c v$. Manzanilla Cacereña had lower contents $(P \leq 0.05)$ than cvs. Manzanilla Sevillana and Carrasqueña. Also, the results (Table 1 and Fig. 1) pointed out that independently of the olive cultivar, the increase of sterilization treatment time-period (at $121 \pm 3{ }^{\circ} \mathrm{C}$ ) enhanced the acrylamide content in olives and brine solutions $(P \leq 0.05)$. As can be inferred from Fig. 1 , the amount of acrylamide increased 65 and $71 \%$ from the less severe thermal treatment (T1) to the highest one (T4), for cvs. Manzanilla Cacereña and Hojiblanca olives, respectively.

Finally, it was also found (based on the HPLC-MS-QQQ data) that the amount of acrylamide in brine solutions was greater than in olives, existing a linear positive relationship between both contents (i.e., high acrylamide concentrations in table olives would correspond to high concentration in brine solutions, $R^{2}=0.994$ for $c v$. Hojiblanca and $R^{2}=0.931$ for $c v$. Manzanilla Cacereña), regardless the olive cultivar and thermal treatment. The higher amount of acrylamide in brine is due to the hydrophilic characteristic of acrylamide, which justify the migration of acrylamide from the olives to the brine solution. Moreover, acrylamide-forming precursors, such as asparagine, that can be found in olives also tend to migrate from the olive to the brine by osmosis (PérezNevado et al., 2018).

This study contributes to strengthening an important aspect for industrial partners, which is the need to minimize the intensity/timeperiod of the thermal sterilization treatments, commonly applied, due to their impacts on the increase of acrylamide content, decreasing the quality of the olives and constituting a health problem. In fact, several authors indicate that a special attention should be paid with the intake of table olives due to the presence of this toxic substance and its negative impact on the human health (Lodolini et al., 2019; Parzefall, 2008). The present study also revealed that a $F_{0}$ value equal or higher than $20 \mathrm{~min}$ was responsible for acrylamide contents greater than $270 \pm 37 \mathrm{ng} \mathrm{g}^{-1}$ and up to $559 \pm 58 \mathrm{ng} \mathrm{g}^{-1}$, which can be a health risk depending on the consumption rate of this high appreciated food, especially for vulnerable elder or children consumers. Indeed, as proposed by Charoenprasert and Mitchell (2014), an acrylamide content lower than $250 \mathrm{ng} \mathrm{g}^{-1}$ would not constituted a serious health problem.

\subsection{Electronic tongue}

3.2.1. Potentiometric behavior of the E-tongue sensor membranes towards acrylamide standard solutions

Although it is expected that the lipid polymeric sensor membranes comprised in the E-tongue may interact with the amine group of the acrylamide molecule $\left(\mathrm{CH}_{2}=\mathrm{CHC}(\mathrm{O}) \mathrm{NH}_{2}\right)$ (Kostritskii et al., 2016), leading to potentiometric signals, the potentiometric behavior was investigated using aqueous acrylamide standard solutions. The 40 potentiometric E-tongue signals were recorded for aqueous acrylamide standard solution $(100 \mathrm{~mL})$, which were obtained by diluting an acrylamide standard solution (2000 $\mathrm{ng} \mathrm{mL}{ }^{-1}$ ) with deionized water (final acrylamide content: $2.5-20 \mathrm{ng} \mathrm{g}^{-1}$ ). The signals gathered by the Etongue sensors during the analysis of the 5 different acrylamide 
Table 2

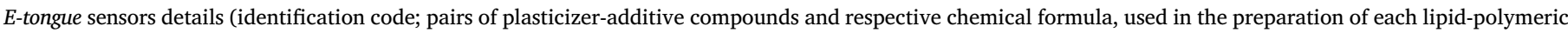

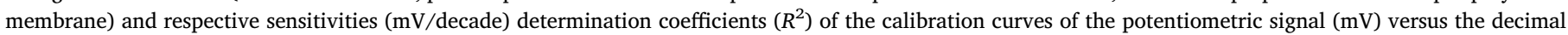
logarithmic of the acrylamide concentration (linear dynamic range: $2.5-20 \mathrm{ng} \mathrm{g}^{-1}$ ).

\begin{tabular}{|c|c|c|c|c|}
\hline $\begin{array}{l}\text { Plasticizer compound }\left(^{*}\right)(\approx 32 \%) \\
\text { (chemical formula) }\end{array}$ & $\begin{array}{l}\text { Additive compound }(* *)(\approx 3 \%) \\
\text { (chemical formula) }\end{array}$ & Sensor ID code $(* * *)$ & $\begin{array}{l}\text { Sensitivity }(* * * *) \\
\bar{x} \pm S E, \mathrm{mV}^{*} \text { decade } \\
-1\end{array}$ & $R^{2}$ \\
\hline \multirow{8}{*}{$\begin{array}{l}\text { Bis(1-butylpentyl) adipate } \\
\qquad\left(\left[-\left(\mathrm{CH}_{2}\right)_{2} \mathrm{COOCH}\left[\left(\mathrm{CH}_{2}\right)_{3} \mathrm{CH}_{3}\right]_{2}\right]_{2}\right)\end{array}$} & \multirow[t]{2}{*}{ Octadecylamine; $\left(\mathrm{CH}_{3}\left(\mathrm{CH}_{2}\right)_{17} \mathrm{NH}_{2}\right)$} & S1:1 & $8.90 \pm 0.25$ & 0.998 \\
\hline & & S2:1 & $5.05 \pm 0.46$ & 0.975 \\
\hline & \multirow[t]{2}{*}{ Oleyl alcohol; $\left(\mathrm{CH}_{3}\left(\mathrm{CH}_{2}\right)_{7} \mathrm{CH}=\mathrm{CH}\left(\mathrm{CH}_{2}\right)_{7} \mathrm{CH}_{2} \mathrm{OH}\right)$} & $\mathrm{S} 1: 2$ & $7.60 \pm 0.15$ & 0.999 \\
\hline & & $\mathrm{S} 2: 2$ & $5.30 \pm 0.33$ & 0.989 \\
\hline & \multirow{2}{*}{$\begin{array}{l}\text { Methyltrioctylammonium chloride; }\left(\left[\mathrm{CH}_{3}\left(\mathrm{CH}_{2}\right)_{6} \mathrm{CH}_{2}\right]_{3} \mathrm{~N}\right. \\
\left.(\mathrm{Cl}) \mathrm{CH}_{3}\right)\end{array}$} & $\mathrm{S} 1: 3$ & - & - \\
\hline & & S2:3 & $11.8 \pm 0.8$ & 0.988 \\
\hline & \multirow[t]{2}{*}{ Oleic acid; $\left(\mathrm{CH}_{3}\left(\mathrm{CH}_{2}\right)_{7} \mathrm{CH}=\mathrm{CH}\left(\mathrm{CH}_{2}\right)_{7} \mathrm{COOH}\right)$} & S1:4 & $7.14 \pm 0.24$ & 0.997 \\
\hline & & S2:4 & $3.61 \pm 0.41$ & 0.962 \\
\hline \multirow[t]{8}{*}{ Dibutyl sebacate; $\left(\left[-\left(\mathrm{CH}_{2}\right)_{4} \mathrm{CO}_{2}\left(\mathrm{CH}_{2}\right)_{3} \mathrm{CH}_{3}\right]\right)$} & \multirow[t]{2}{*}{ Octadecylamine; $\left(\mathrm{CH}_{3}\left(\mathrm{CH}_{2}\right)_{17} \mathrm{NH}_{2}\right)$} & S1:5 & $8.40 \pm 0.22$ & 0.998 \\
\hline & & S2:5 & $5.46 \pm 0.08$ & 0.999 \\
\hline & \multirow{2}{*}{ Oleyl alcohol; $\left(\mathrm{CH}_{3}\left(\mathrm{CH}_{2}\right)_{7} \mathrm{CH}=\mathrm{CH}\left(\mathrm{CH}_{2}\right)_{7} \mathrm{CH}_{2} \mathrm{OH}\right)$} & S1:6 & $9.98 \pm 0.22$ & 0.998 \\
\hline & & S2:6 & $8.53 \pm 1.25$ & 0.939 \\
\hline & \multirow{2}{*}{$\begin{array}{l}\text { Methyltrioctylammonium chloride; }\left(\left[\mathrm{CH}_{3}\left(\mathrm{CH}_{2}\right)_{6} \mathrm{CH}_{2}\right]_{3} \mathrm{~N}\right. \\
\left.(\mathrm{Cl}) \mathrm{CH}_{3}\right)\end{array}$} & S1:7 & $6.90 \pm 0.26$ & 0.996 \\
\hline & & S2:7 & $5.66 \pm 0.25$ & 0.994 \\
\hline & \multirow[t]{2}{*}{ Oleic acid; $\left(\mathrm{CH}_{3}\left(\mathrm{CH}_{2}\right)_{7} \mathrm{CH}=\mathrm{CH}\left(\mathrm{CH}_{2}\right)_{7} \mathrm{COOH}\right)$} & S1:8 & $7.59 \pm 0.26$ & 0.996 \\
\hline & & $\mathrm{S} 2: 8$ & $4.56 \pm 0.34$ & 0.983 \\
\hline \multirow{8}{*}{ 2-nitrophenyl-octyl ether $\left(\mathrm{O}_{2} \mathrm{NC}_{6} \mathrm{H}_{4} \mathrm{O}\left(\mathrm{CH}_{2}\right)_{7} \mathrm{CH}_{3}\right)$} & \multirow[t]{2}{*}{ Octadecylamine; $\left(\mathrm{CH}_{3}\left(\mathrm{CH}_{2}\right)_{17} \mathrm{NH}_{2}\right)$} & S1:9 & $7.59 \pm 0.26$ & 0.996 \\
\hline & & S2:9 & - & - \\
\hline & \multirow[t]{2}{*}{ Oleyl alcohol; $\left(\mathrm{CH}_{3}\left(\mathrm{CH}_{2}\right)_{7} \mathrm{CH}=\mathrm{CH}\left(\mathrm{CH}_{2}\right)_{7} \mathrm{CH}_{2} \mathrm{OH}\right)$} & $\mathrm{S} 1: 10$ & $7.75 \pm 0.25$ & 0.997 \\
\hline & & S2:10 & $5.64 \pm 0.34$ & 0.989 \\
\hline & \multirow{2}{*}{$\begin{array}{l}\text { Methyltrioctylammonium chloride; }\left(\left[\mathrm{CH}_{3}\left(\mathrm{CH}_{2}\right)_{6} \mathrm{CH}_{2}\right]_{3} \mathrm{~N}\right. \\
\left.(\mathrm{Cl}) \mathrm{CH}_{3}\right)\end{array}$} & S1:11 & $8.77 \pm 0.11$ & 0.999 \\
\hline & & S2:11 & $14.5 \pm 0.6$ & 0.994 \\
\hline & \multirow[t]{2}{*}{ Oleic acid; $\left(\mathrm{CH}_{3}\left(\mathrm{CH}_{2}\right)_{7} \mathrm{CH}=\mathrm{CH}\left(\mathrm{CH}_{2}\right)_{7} \mathrm{COOH}\right)$} & $\mathrm{S} 1: 12$ & $7.45 \pm 0.28$ & 0.996 \\
\hline & & $\mathrm{S} 2: 12$ & $9.25 \pm 0.66$ & 0.985 \\
\hline \multirow{8}{*}{$\begin{array}{l}\text { Tris(2-ethylhexyl) phosphate } \\
\qquad\left(\left[\mathrm{CH}_{3}\left(\mathrm{CH}_{2}\right)_{3} \mathrm{CH}\left(\mathrm{C}_{2} \mathrm{H}_{5}\right) \mathrm{CH}_{2} \mathrm{O}\right]_{3} \mathrm{P}(\mathrm{O})\right)\end{array}$} & \multirow[t]{2}{*}{ Octadecylamine; $\left(\mathrm{CH}_{3}\left(\mathrm{CH}_{2}\right)_{17} \mathrm{NH}_{2}\right)$} & $\mathrm{S} 1: 13$ & $14.2 \pm 0.78$ & 0.991 \\
\hline & & S2:13 & $19.4 \pm 1.4$ & 0.984 \\
\hline & \multirow{2}{*}{ Oleyl alcohol; $\left(\mathrm{CH}_{3}\left(\mathrm{CH}_{2}\right)_{7} \mathrm{CH}=\mathrm{CH}\left(\mathrm{CH}_{2}\right)_{7} \mathrm{CH}_{2} \mathrm{OH}\right)$} & S1:14 & $7.26 \pm 0.18$ & 0.998 \\
\hline & & S2:14 & $-17.5 \pm 1.1$ & 0.989 \\
\hline & \multirow{2}{*}{$\begin{array}{l}\text { Methyltrioctylammonium chloride; }\left(\left[\mathrm{CH}_{3}\left(\mathrm{CH}_{2}\right)_{6} \mathrm{CH}_{2}\right]_{3} \mathrm{~N}\right. \\
\left.(\mathrm{Cl}) \mathrm{CH}_{3}\right)\end{array}$} & S1:15 & $5.66 \pm 0.92$ & 0.950 \\
\hline & & S2:15 & $7.34 \pm 0.18$ & 0.998 \\
\hline & \multirow[t]{2}{*}{ Oleic acid; $\left(\mathrm{CH}_{3}\left(\mathrm{CH}_{2}\right)_{7} \mathrm{CH}=\mathrm{CH}\left(\mathrm{CH}_{2}\right)_{7} \mathrm{COOH}\right)$} & S1:16 & $7.71 \pm 0.20$ & 0.998 \\
\hline & & S2:16 & $11.6 \pm 0.8$ & 0.986 \\
\hline \multirow{8}{*}{ Dioctyl phenylphosphonate $\left(\mathrm{C}_{6} \mathrm{H}_{5} \mathrm{P}(\mathrm{O})\left[\mathrm{O}\left(\mathrm{CH}_{2}\right)_{7} \mathrm{CH}_{3}\right]_{2}\right)$} & \multirow[t]{2}{*}{ Octadecylamine; $\left(\mathrm{CH}_{3}\left(\mathrm{CH}_{2}\right)_{17} \mathrm{NH}_{2}\right)$} & S1:17 & $7.67 \pm 0.25$ & 0.997 \\
\hline & & S2:17 & $-6.56 \pm 0.02$ & 0.999 \\
\hline & \multirow[t]{2}{*}{ Oleyl alcohol; $\left(\mathrm{CH}_{3}\left(\mathrm{CH}_{2}\right)_{7} \mathrm{CH}=\mathrm{CH}\left(\mathrm{CH}_{2}\right)_{7} \mathrm{CH}_{2} \mathrm{OH}\right)$} & $\mathrm{S} 1: 18$ & $7.09 \pm 0.23$ & 0.997 \\
\hline & & S2:18 & $-3.66 \pm 0.66$ & 0.912 \\
\hline & \multirow{2}{*}{$\begin{array}{l}\text { Methyltrioctylammonium chloride; }\left(\left[\mathrm{CH}_{3}\left(\mathrm{CH}_{2}\right)_{6} \mathrm{CH}_{2}\right]_{3} \mathrm{~N}\right. \\
\left.(\mathrm{Cl}) \mathrm{CH}_{3}\right)\end{array}$} & S1:19 & $7.48 \pm 0.27$ & 0.996 \\
\hline & & S2:19 & $3.65 \pm 0.10$ & 0.998 \\
\hline & \multirow[t]{2}{*}{ Oleic acid; $\left(\mathrm{CH}_{3}\left(\mathrm{CH}_{2}\right)_{7} \mathrm{CH}=\mathrm{CH}\left(\mathrm{CH}_{2}\right)_{7} \mathrm{COOH}\right)$} & $\mathrm{S} 1: 20$ & $7.62 \pm 0.21$ & 0.998 \\
\hline & & $\mathrm{S} 2: 20$ & $-3.15 \pm 0.11$ & 0.997 \\
\hline
\end{tabular}

(*) All plasticizers were selectophore ${ }^{\mathrm{TM}}$ grade from Fluka, with purity $\geq 97 \%$.

(**) All additives were from Fluka, with purity $\geq 97 \%$.

$(* * *)$ Sensor identification number: $\mathrm{S}$ - sensor; number: code of the sensor array; 2nd number plasticizer-additive combination.

$(* * * *) \bar{x}$ : mean sensitivity value (mV/decade); $S E$ : standard error ( $\mathrm{mV} /$ decade).

standard aqueous solutions, showed CV\% ranging from 0.1 to $3.5 \%$ and $2.0-9.8 \%$ for intra-day and inter-day repeatability, pointing out the sensors' stability. Besides, all the E-tongue polymeric membranes showed an increase of the potential response (in absolute value) with the increase of the acrylamide concentration, showing that the recorded signals were due to presence of acrylamide. Moreover, the 40 sensors showed a substantial potential signal increase (varying from +10 to $+260 \mathrm{mV}$ ) or decrease $(-7$ to $-220 \mathrm{mV})$ after the first addition of acrylamide (in comparison with the signal recorded for the deionized water), demonstrating that the E-tongue sensors respond, at least, to acrylamide concentrations as low as $2.5 \mathrm{ng} \mathrm{g}^{-1}$. Thus, this concentration, could be assumed as a limit of detection (LOD) per excess, since a non-response potential threshold was not observed for any of the Etongue sensors (Wu et al., 2009). However, it should be noticed that, as recently discussed by Oleneva et al. (2019), establishing LOD in multivariate calibration is a non-trivial task due to the complexity and dimensionality of the experimental data. In the present study, for the studied acrylamide concentration dynamic range $\left(2.5-20 \mathrm{ng} \mathrm{g}^{-1}\right)$ and E-tongue sensors, positive or negative linear relationships $\left(0.912 \leq R^{2} \leq 0.999\right.$, Table 2) were observed for the potential difference $(\mathrm{mV})$ versus the decimal logarithm of the acrylamide concentration (in $\mathrm{ng} \cdot \mathrm{g}^{-1}$ ). It should be also noticed that for all the 20 different plasticizer/additive pairs showed satisfactory mean sensitivities (slope values of the linear regressions, Table 2), varying from $+3.61( \pm 0.41)$ to $+19.4( \pm 1.4) \mathrm{mV} /$ decade, for positive calibration, and ranging from $-17.5( \pm 1.1)$ to $-3.15( \pm 0.11) \mathrm{mV} /$ decade, for negative calibration. The results also pointed out that if, in general, all sensors and respective replicas had a similar potentiometric interaction behavior towards acrylamide (same sensitivity magnitude and sign), some of them showed an opposite behavior, which could be tentatively attributed to slight differences of the composition and physical properties (transparency and porosity) of the membranes resulting from the drop-by-drop technique applied that may lead to the formation of inhomogeneous membranes (Dias et al., 2014). It should be also pointed out that, apparently, plasticizer tris(2-ethylhexyl) phosphate seems to enhance the sensitivity of the sensor membranes compared to the other 4 plasticizers used (i.e., bis(1-butylpentyl) adipate, dibutyl sebacate, 2nitrophenyl-octyl ether and dioctyl phenylphosphonate).

3.2.2. Assessing acrylamide concentration in table olives and respective brine solutions using the potentiometric E-tongue

The possibility of applying the E-tongue together with multivariate 
Table 3

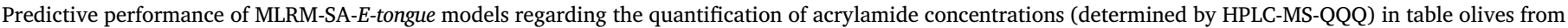

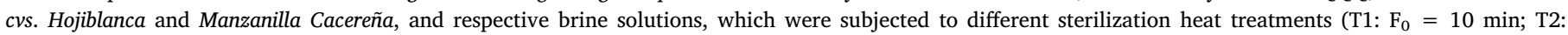
$\mathrm{F}_{0}=15 \mathrm{~min}, \mathrm{~T} 3: \mathrm{F}_{0}=20 \mathrm{~min}$, and $\mathrm{T} 4: \mathrm{F}_{0}=25 \mathrm{~min}$, at $121 \pm 3{ }^{\circ} \mathrm{C}$ ).

\begin{tabular}{|c|c|c|c|c|c|c|c|}
\hline \multirow[t]{3}{*}{ Olive cultivar } & \multirow[t]{3}{*}{ Acrylamide } & \multirow[t]{3}{*}{ Concentration range $\left(n g \cdot g^{-1}\right)^{a}$} & \multicolumn{5}{|c|}{ E-tongue-MLR-SA models ${ }^{\mathrm{b}}$} \\
\hline & & & \multirow[t]{2}{*}{ No of sensors ${ }^{c}$} & \multicolumn{2}{|c|}{ Determination coefficient $\left(R^{2}\right)$} & \multicolumn{2}{|c|}{ Root-mean-square errors (RMSE, $\mathrm{ng} \cdot \mathrm{g}^{-1}$ ) } \\
\hline & & & & LOO-CV ${ }^{d}$ & Repeated $K$-fold-CV ${ }^{\mathrm{e}}$ & LOO-CV ${ }^{\mathrm{d}}$ & Repeated $K$-fold-CV \\
\hline \multirow[t]{2}{*}{ cv. Hojiblanca } & Table olives & {$[161.6,461.6]$} & $15^{\mathrm{f}}$ & 0.995 & $0.99 \pm 0.01$ & 7.6 & $12 \pm 8$ \\
\hline & Brine solution & {$[201.3,622.5]$} & $14^{g}$ & 0.985 & $0.97 \pm 0.03$ & 20.0 & $28 \pm 14$ \\
\hline \multirow[t]{2}{*}{ cv. Manzanilla Cacereña } & Table olives & {$[127.5,382.6]$} & $10^{\mathrm{h}}$ & 0.974 & $0.97 \pm 0.02$ & 15.5 & $18 \pm 8$ \\
\hline & Brine solution & {$[178.6,516.6]$} & $13^{\mathrm{i}}$ & 0.993 & $0.99 \pm 0.01$ & 10.9 & $14 \pm 6$ \\
\hline
\end{tabular}

\footnotetext{
a Experimental acrylamide concentration levels (in $\mathrm{ng}^{-\mathrm{g}^{-1}}$ ) determined by HPLC in the table olives and respective brine solutions.

b Multivariate linear regression model (MLRM) based on sub-sets of potentiometric sensors, established using the simulated annealing (SA) algorithm, selected

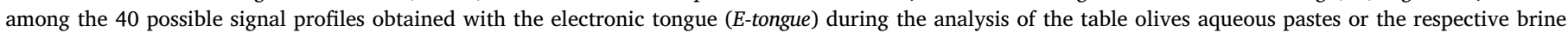
solutions.

c Number of signals included in the MLRM-SA-E-tongue model, selected from the 40 electrochemical signals recorded by E-tongue during analysis of each during the analysis table olives aqueous paste or the respective brine solution.

d LOO-CV: leave-one-out cross validation procedure.

e Repeated $K$-fold-CV: cross-validation procedure with 4 folds, ensuring that at least $25 \%$ of the original data are used for internal validation, and 10 repetitions.

f Sensors from the E-tongue device used in the best MLRM-SA-E-tongue model (1st array: S1:1, S1:5, S1:6, S1:8, S1:14, S1:15, S1:19; 2nd array: S2:2, S2:4, S2:8, S2:11, S2:13, S2:15, S2:16, S2:20).

$\mathrm{g}$ Sensors from the E-tongue device used in the best MLRM-SA-E-tongue model (1st array: S1:1, S1:2, S1:6, S1:16, S1:20; 2nd array: S2:1, S2:2, S2:10, S2:11, S2:12, S2:13, S2:14, S2:17, S2:19).

h Sensors from the E-tongue device used in the best MLRM-SA-E-tongue model (1st array: S1:8, S1:16, S1:17, S1:18; 2nd array: S2:8, S2:10, S2:12, S2:13, S2:19, S2:20).

i Sensors from the E-tongue device used in the best MLRM-SA-E-tongue model (1st array: S1:4, S1:5, S1:10, S1:13, S1:14, S1:19, S1:20; 2nd array: S2:2, S2:4, S2:8, S2:15, S2:18, S2:19).
}

statistical linear techniques (MLRM-SA) to monitor the acrylamide formation due to the thermal sterilization treatments applied during the production of table olives (cvs. Hojiblanca or Manzanilla Cacereña), was investigated. Since acrylamide is soluble in water both table olives and brine solutions were evaluated due to the expected migration of acrylamide from the olives to the brine solution. As in previous works, where chemical and sensory attributes of commercial table olives were quantitatively assessed using an E-tongue (Marx et al., 2017a,c), two CV variants were used to evaluate the performance of the MLRM-SA-Etongue models, namely the LOO-CV and repeated $K$-fold-CV procedures (10 repeats $\times 4$ folds). The goodness of fitting parameters of the models for both matrices (table olives and brine solution) and olive cultivars (cvs. Hojiblanca or Manzanilla Cacereña) are given in Table 3, together with information of the number and type of sensors included in each MLRM established. Based on the $R^{2}$ and RMSE values (LOO-CV: $0.974 \leq R^{2} \leq 0.995$ and $7.6 \leq R M S E \leq 20 \mathrm{ng} \mathrm{g}^{-1}$; repeated $K$-fold$\mathrm{CV}: 0.97 \pm 0.03 \leq R^{2} \leq 0.99 \pm 0.01$ and $12 \pm 8 \leq R M S E \leq$ $28 \pm 14 \mathrm{ng} \mathrm{g}^{-1}$ ) demonstrated the satisfactory quantitative predictive performance of the potentiometric E-tongue for quantifying acrylamide concentrations in both matrices and for both olive cultivars under study. Fig. 2 allows verifying the quality of the results achieved for the repeated $K$-fold-CV variant. The capability of accurately assessing acrylamide in the brine solutions using the E-tongue approach is of major practical relevance. Indeed, since positive linear correlations could be established between the acrylamide concentrations (determined by HPLC-MS-QQQ) in table olives and in the respective brine solutions $\left(R^{2}=0.994\right.$ for $c v$. Hojiblanca and $R^{2}=0.931$ for $c v$. Manzanilla Cacereña), it would be possible to establish a non-destructive indirect quantification method of acrylamide in table olives based on the analysis of the respective brine solutions, allowing keeping the integrity of the food product.

Finally, the application of MLRM-SA-E-tongue models as a complementary accurate analytical approach for assessing acrylamide contents in table olives or brine solutions table olives was further studied as suggested by Roig and Thomas (2003a, 2003b). So, single linear regressions were established between the acrylamide concentrations predicted by the MLRM-SA-E-tongue models and the experimental values determined by HPLC-MS-QQQ, being investigated if the slope and intercept values were statistically equal to one and zero, respectively (i.e., perfect linear fit). The parameters of the single linear regressions $\left(R^{2}\right.$, slope and intercept values and the respective $95 \%$ confidence intervals) for both cross-validation variants are shown in Table 4. The results demonstrate that, at $5 \%$ significance level, the slope and intercept values were statistically equal to the expected theoretic values. These results confirmed that the MLRM-SA-E-tongue approach could be used for monitoring the effect of the thermal treatment on the increasing acrylamide concentration observed with the increase of the sterilization time-period of the Californian-style black table olives. Therefore, the potentiometric E-tongue seem to be a fast and cost-effective possible complementary/alternative technique to the standard HPLC-MS-QQQ technique commonly used to assess acrylamide in table olives subjected to industrial typical heat sterilization processes. The satisfactory performance of the E-tongue is of great relevance since, although no legal threshold has been established for acrylamide in table olives, olives in brine are included in the non-exhaustive list of foods, for which the competent authorities in the Member States of the EU should monitor the presence of acrylamide (Commission Recommendation (EU) 2019/1888, 2019).

\section{Conclusions}

The results demonstrated that the acrylamide contents of Californian-style black table olives depend on the olive cultivar (being $c v$. Manzanilla Cacereña olives less affected compared to $c v$. Hojiblanca olives) as well as on the intensity/time-period of the thermal sterilization treatment applied (lower time-periods implied lower concentrations) for the preservation of olives. So, reducing the intensity/timeperiod of the thermal sterilization treatment decreases the synthesis of acrylamide, minimizing the possible health concerns related to the acrylamide intake due olives consumption. The study also showed that a potentiometric E-tongue could be used to monitor the concentration of acrylamide in Californian-style black table olives as well as on the respective brines. This finding allow foreseeing the E-tongue application as a detection analytical tool complementary or even alternative to the 
(A) cv. Hojiblanca

MLRM-SA-E-tongue predictive models (repeated $K$-fold-CV: 10 repeats $\times 4$ folds)

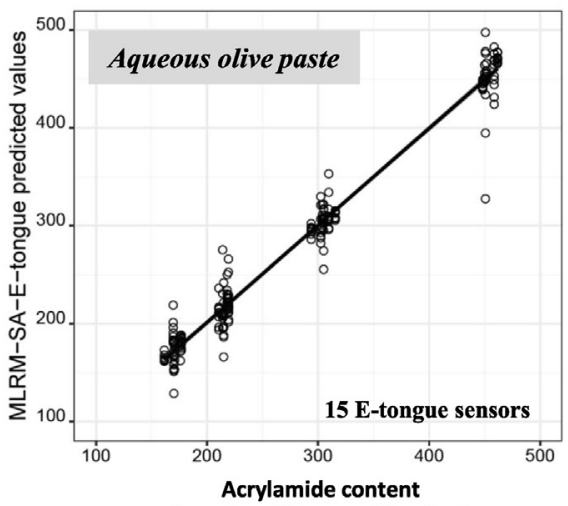

(ng.g ${ }^{-1}$ Hojiblanca table olive)

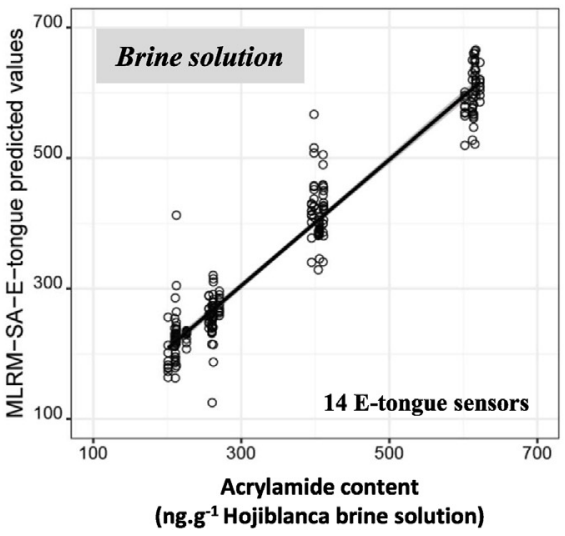

(B) cv. Manzanilla Cacereña

MLRM-SA-E-tongue predictive models (repeated $K$-fold-CV: 10 repeats $\times 4$ folds)

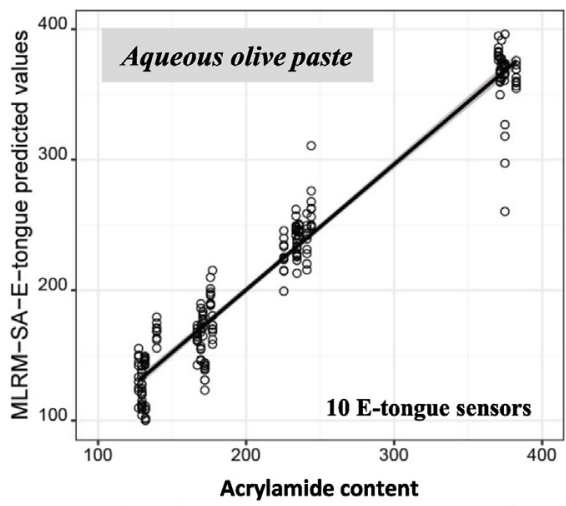

(ng. - $^{-1}$ Manzanilla Cacereña table olive)

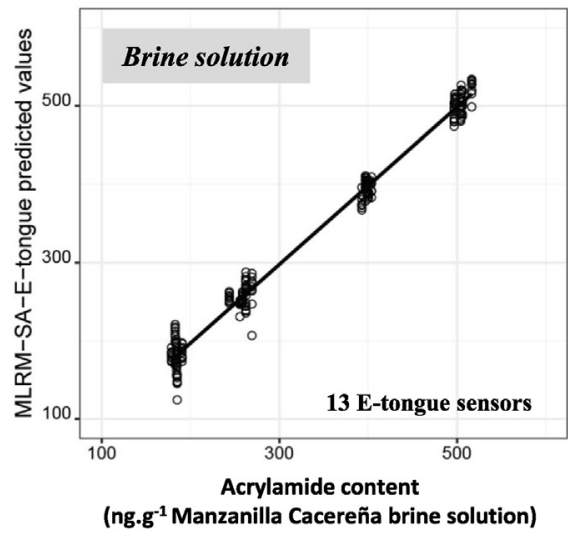

Fig. 2. Acrylamide concentrations (ng. $g^{-1}$ ) predicted by the MLRM-SA-E-tongue models (repeated $K$-fold-CV variant: 10 repeats $\times 4$ folds), established based on different sub-sets of sensors (10-15 E-tongue sensors) selected using the SA algorithm, versus the experimental concentrations determined by the HPLC-MS-QQQ, during the analysis of Californian-style black olives (aqueous olive pastes and respective diluted brine solutions), subjected to different thermal sterilization treatments (T1: $\mathrm{F}_{0}=10 \mathrm{~min} ; \mathrm{T} 2: \mathrm{F}_{0}=15 \mathrm{~min}, \mathrm{~T} 3: \mathrm{F}_{0}=20 \mathrm{~min}$, and $\mathrm{T} 4: \mathrm{F}_{0}=25 \mathrm{~min}$, at $\left.121 \pm 3{ }^{\circ} \mathrm{C}\right)$ for: (A) cv. Hojiblanca; and, (B) $c v$. Manzanilla Cacereña.

conventional chromatographic techniques commonly used to detect acrylamide in table olives. Furthermore, the capability of the multisensor device to assess the acrylamide contents in the brines and the possibility of establishing a linear correlation between the concentrations in table olives and respective brine solutions also allows foreseeing the brine analysis as a practical, indirect and non-destructive acrylamide detection method for table olives. Finally, since E-tongue is a fast, cost-effective, accurate, user-friendly and portable method for assessing the acrylamide content of olives in cans after undergoing sterilization heat treatments, turns out to be of utmost interest for future industrial applications.

\section{CRediT authorship contribution statement}

Daniel Martín-Vertedor: Conceptualization, Data curation, Formal analysis, Writing - original draft, Writing - review \& editing. Nuno Rodrigues: Data curation, Writing - original draft, Writing - review \& editing. Ítala M.G. Marx: Data curation, Formal analysis, Writing original draft. Luís G. Dias: Funding acquisition, Methodology, Writing - original draft. Ana C.A. Veloso: Funding acquisition,

Table 4

Parameters of the single linear regressions established between the acrylamide contents predicted by the MLRM-SA-E-tongue models (LOO-CV and repeated $K$-fold$\mathrm{CV}$ ) and the experimental acrylamide concentrations determined by HPLC-MS-QQQ: coefficient of determination $\left(R^{2}\right)$; slopes, intercept values and respective confidence intervals (CI) at 95\%.

\begin{tabular}{|c|c|c|c|c|c|c|c|c|c|c|c|}
\hline \multirow[t]{2}{*}{ Olive cultivar } & \multirow[t]{2}{*}{ Acrylamide } & \multicolumn{5}{|c|}{ LOO-CV } & \multicolumn{5}{|c|}{ Repeated $K$-fold-CV ${ }^{\mathrm{b}}$} \\
\hline & & $R^{2}$ & Slope & Slope $\mathrm{CI}^{\mathrm{c}}$ & Intercept & Intercept $\mathrm{CI}^{\mathrm{d}}$ & $R^{2}$ & Slope & Slope $\mathrm{CI}^{\mathrm{c}}$ & Intercept & Intercept $\mathrm{CI}^{\mathrm{d}}$ \\
\hline \multirow[t]{2}{*}{ cv. Hojiblanca } & Table olives & 0.995 & 1.002 & {$[0.972,1.032]$} & -0.4 & {$[-9.6,8.8]$} & 0.949 & 1.026 & {$[0.996,1.056]$} & -4.3 & {$[-13.6,5.0]$} \\
\hline & Brine solutions & 0.985 & 0.991 & {$[0.936,1.045]$} & 2.1 & {$[-19.8,24.1]$} & 0.909 & 0.996 & {$[0.956,1.036]$} & 4.4 & {$[-11.8,20.7]$} \\
\hline \multirow[t]{2}{*}{ cv. Manzanilla Cacereña } & Table olives & 0.974 & 0.942 & {$[0.916,1.059]$} & -9.0 & {$[-14.8,20.4]$} & 0.945 & 0.994 & {$[0.963,1.024]$} & 1.5 & {$[-6.0,9.1]$} \\
\hline & Brine solutions & 0.993 & 1.000 & {$[0.964,1.039]$} & -1.0 & {$[-14.4,12.5]$} & 0.984 & 1.008 & {$[0.992,1.024]$} & -5.2 & {$[-11.0,0.5]$} \\
\hline
\end{tabular}

\footnotetext{
a LOO-CV (leave-one-out cross-validation).

b Repeated $K$-fold-CV (4 folds $\times 10$ repeats).

c $95 \%$ slope confidence interval.

d $95 \%$ intercept confidence interval.
} 
Methodology, Writing - original draft. José Alberto Pereira: Conceptualization, Formal analysis, Funding acquisition, Supervision, Writing - review \& editing. António M. Peres: Conceptualization, Formal analysis, Funding acquisition, Supervision, Writing - review \& editing.

\section{Declaration of competing interest}

The authors declare that they have no known competing financial interests or personal relationships that could have appeared to influence the work reported in this paper.

\section{Acknowledgements}

Daniel Martín-Vertedor thanks the mobility grant of the Consejería de Educación y Empleo of the Junta de Extremadura to work with a scholarship at the Polytechnic Institute of Bragança for 4 months (Resolución de 18 de julio de 2019, DOE de 25 de julio de 2019, no 143) (Expedient number A28). The authors are grateful to the Foundation for Science and Technology (FCT, Portugal) and FEDER under Program PT2020 for financial support to CIMO (UIDB/00690/ 2020) and to CEB (UIDB/04469/2020) units and to BioTecNorte operation (NORTE-01-0145-FEDER-000004) funded by the European Regional Development Fund under the scope of Norte2020 - Programa Operacional Regional do Norte. Nuno Rodrigues thanks to National funding by FCT- Foundation for Science and Technology, P.I., through the institutional scientific employment program-contract. The authors wish to thank to the Elemental and Molecular Analysis Service belonging to the Research Support Service of the University of Extremadura by the development of acrylamide determination method and $\mathrm{M}^{\mathrm{a}}$ Dolores López Soto and Elena Rodríguez Paniagua for their help in the performance of this study.

\section{References}

Asnaashari, M., Esmaeilzadeh Kenari, R., Farahmandfar, R., Taghdisi, S. M., \& Abnous, K. (2018). Fluorescence quenching biosensor for acrylamide detection in food products based on double-stranded DNA and gold nanoparticles. Sensors and Actuators B: Chemical, 265, 339-345. https://doi.org/10.1016/j.snb.2018.03.083.

Asnaashari, M., Kenari, R. E., Farahmandfar, R., Abnous, K., \& Taghdisi, S. M. (2019). An electrochemical biosensor based on hemoglobin-oligonucleotides-modified electrode for detection of acrylamide in potato fries. Food Chemistry, 271, 54-61. https://doi. org/10.1016/j.foodchem.2018.07.150.

Cadima, J., Cerdeira, J. O., \& Minhoto, M. (2004). Computational aspects of algorithms for variable selection in the context of principal components. Computational Statistics \& Data Analysis, 47, 225-236. https://doi.org/10.1016/j.csda.2003.11.001.

Casado, F. J., \& Montaño, A. (2008). Influence of processing conditions on acrylamide content in black ripe olives. Journal of Agricultural and Food Chemistry, 56, 2021-2027. https://doi.org/10.1021/jf072960b.

Casado, F. J., Montaño, A., Spitzner, D., \& Carle, R. (2013). Investigations into acrylamide precursors in sterilized table olives: Evidence of a peptic fraction being responsible for acrylamide formation. Food Chemistry, 141, 1158-1165. https://doi.org/10.1016/ j.foodchem.2013.04.040.

Charoenprasert, S., \& Mitchell, A. (2014). Influence of California-style black ripe olive processing on the formation of acrylamide. Journal of Agricultural and Food Chemistry, 62(34), 8716-8721. https://doi.org/10.1021/jf5022829.

Commission Recommendation (EU) 2019/1888 (2019). Commission Recommendation (EU) 2019/1888 of 7 November 2019 on the monitoring of the presence of acrylamide in certain foods. European Union L291. (document 32019H1888), 31-33 http://data.europa. eu/eli/reco/2019/1888/oj.

Crawford, L. M., \& Wang, S. C. (2019). Comparative study of four analytical methods for the routine determination of acrylamide in black ripe olives. Journal of Agricultural and Food Chemistry, 67(46), 12633-12641. https://doi.org/10.1021/acs.jafc. $9 \mathrm{~b} 00363$.

Dias, L. G., Fernandes, A., Veloso, A. C. A., Machado, A. A. S. C., Pereira, J. A., \& Peres, A. M. (2014). Single-cultivar extra virgin olive oil classification using a potentiometric electronic tongue. Food Chemistry, 160, 321-329. https://doi.org/10.1016/j. foodchem.2014.03.072.

Efsa (2015). Scientific opinion on acrylamide in food. EFSA panel on contaminants in the food chain (CONTAM). EFSA Journal, 13(6), 4104. https://doi.org/10.2903/j. efsa. 2015.4104.

Fernández, A., Talaverano, M. I., Pérez-Nevado, F., Boselli, E., Cordeiro, A. M., Martillanes, S., et al. (2020). Evaluation of phenolics and acrylamide and their bioavailability in high hydrostatic pressure treated and fried table olives. Journal of
Food Processing and Preservation. https://doi.org/10.1111/jfpp.14384.

Field, A. (2009). Discovering statistics using SPSS (3rd ed.). London: Sage Publications Ltd.

IARC (1994). IARC monographs on the evaluation of carcinogenic risks to humans: Some industrial chemicals. Acrylamide, Vol. 60, Lyon, France: International Agency for Research on Cancer389-433.

Kobayashi, Y., Habara, M., Ikezazki, H., Chen, R., Naito, Y., \& Toko, K. (2010). Advanced taste sensors based on artificial lipids with global selectivity to basic taste qualities and high correlation to sensory scores. Sensors, 10, 3411-3443. https://doi.org/10. 3390/s100403411.

Kostritskii, A. Y., Kondinskaia, D. A., Nesterenko, A. M., \& Gurtovenko, A. A. (2016). Adsorption of synthetic cationic polymers on model phospholipid membranes: Insight from atomic-scale molecular dynamics simulations. Langmuir, 32(40), 10402-10414. https://doi.org/10.1021/acs.langmuir.6b02593.

Lodolini, E. M., Cabrera-Bañegil, M., Fernández, A., Delgado-Adámez, J., Ramírez, R., \& Martín-Vertedor, D. (2019). Monitoring of acrylamide and phenolic compounds in table olive after high hydrostatic pressure and cooking treatments. Food Chemistry, 522(286), 250-259. https://doi.org/10.1016/j.foodchem.2019.01.191.

Martín-Vertedor, D., Fernández, A., Hernández, A., Arias-Calderón, R., Delgado-Adámez, J., \& Pérez-Nevado, F. (2020). Acrylamide reduction after phenols addition to Californian-style black olives. Food Control, 108. https://doi.org/10.1016/j.foodcont. 2019.106888.

Marx, Í., Rodrigues, N., Dias, L. G., Veloso, A. C. A., Pereira, J. A., Drunkler, D. A., et al. (2017a). Sensory classification of table olives using an electronic tongue: Analysis of aqueous pastes and brines. Talanta, 162, 98-106. https://doi.org/10.1016/j.talanta. 2016.10.028.

Marx, Í. M. G., Rodrigues, N., Dias, L. G., Veloso, A. C. A., Pereira, J. A., Drunkler, D. A., et al. (2017b). Quantification of table olives' acid, bitter and salty tastes using potentiometric electronic tongue fingerprints. LWT-Food Science and Technology, 79, 394-401. https://doi.org/10.1016/j.lwt.2017.01.060.

Marx, I., Rodrigues, N., Dias, L. G., Veloso, A. C. A., Pereira, J. A., Drunkler, D. A., et al. (2017c). Assessment of table olives' organoleptic defects intensities based on the potentiometric fingerprint recorded by an electronic tongue. Food and Bioprocess Technology, 10(7), 1310-1323. https://doi.org/10.1007/s11947-017-1902-7.

Ministerio de la Presidencia (2001). Real Decreto 1230/2001, de 8 de noviembre, Reglamentación técnico-sanitaria para la elaboración, circulación y venta de las aceitunas de mesa. Boletín Oficial del Estado (BOE) núm. 279, de 21 de noviembre de 2001, 42587-42594. Madrid: Ministerio de la Presidencia.

Ministerio de la Presidencia (2016). Real Decreto 679/2016 (2016), de 16 de diciembre norma de calidad de las aceitunas de mesa. Boletín Oficial del Estado (BOE) núm. 304, de 17 de diciembre de 2016. Madrid: Ministerio de la Presidencia88525-88533.

Montaño, A., Casado, F. J., \& Carle, R. (2015). Acrylamide in table olives. Acrylamide in food: Analysis, content and potential health effects, Vol. 229https://doi.org/10.1016/ B978-0-12-802832-2.00012-7.

Mülazimoğlu, A. D., Sağir, S., Durmus, A., \& Mülazimoğlu, I. E. (2017). A comparative study of electrochemical behaviors of acrylamide on glassy carbon, platinum and gold electrode surfaces by cyclic voltammetry. Eurasian Journal of Analytical Chemistry, 12(1), 15-21. https://doi.org/10.12973/ejac.2017.00141a.

Oleneva, E., Khaydukova, M., Ashina, J., Yaroshenko, I., Jahatspanian, I., Legin, A., et al. (2019). A simple procedure to assess limit of detection for multisensor systems. Sensors, 19(6), 1359. https://doi.org/10.3390/s19061359.

Parzefall, W. (2008). Minireview on the toxicity of dietary acrylamide. Food Chemistry Toxicology, 46, 360-1364. https://doi.org/10.1016/j.fct.2007.08.027.

Pérez-Nevado, F., Cabrera-Bañegil, M., Repilado, E., Martillanes, S., \& Martín-Vertedor, D. (2018). Effect of different baking treatments on the acrylamide formation and phenolic compounds in Californian-style black olives. Food Control, 94, 22-29. https://doi.org/10.1016/j.foodcont.2018.06.021.

Prata, R., Pereira, J. A., Rodrigues, N., Dias, L. G., Veloso, A. C. A., Casal, S., et al. (2018). Olive oil total phenolic contents and sensory sensations trends during oven and microwave heating processes and their discrimination using an electronic tongue. Journal of Food Quality. https://doi.org/10.1155/2018/7826428.

Roig, B., \& Thomas, O. (2003a). Rapid estimation of global sugars by UV photodegradation and UV spectrophotometry. Analytica Chimica Acta, 477, 325-329. https://doi.org/10.1016/S0003-2670(02)01427-7.

Roig, B., \& Thomas, O. (2003b). UV monitoring of sugars during wine making. Carbohydrate Research, 338, 79-83. https://doi.org/10.1016/S0008-6215(02) 00396-8.

Sani, N. D. M., Heng, L. Y., Marugan, R. S. P. M., \& Rajab, N. F. (2018). Electrochemical DNA biosensor for potential carcinogen detection in food sample. Food Chemistry, 269, 503-510. https://doi.org/10.1016/j.foodchem.2018.07.035.

Tang, S., Avena-Bustillos, R. J., Lear, M., Sedej, I., Holstege, D. M., Friedman, M., et al. (2016). Evaluation of thermal processing variables for reducing acrylamide in canned black ripe olives. Journal of Food Engineering, 191, 124-130. https://doi.org/10. 1016/j.jfoodeng.2016.07.011.

Venables, W. N., \& Ripley, B. D. (2002). Modern applied statistics with $S$ (statistics and computing) (4th ed.). New York: Springerhttps://doi.org/10.1007/978-0-387-2170622002.

Wu, J., Chumbimuni-Torres, K. Y., Galik, M., Thammakhet, C., Haake, D. A., \& Wang, J. (2009). Potentiometric detection of DNA hybridization using enzyme-induced metallization and a silver ion selective electrode. Analytical Chemistry, 81(24), 10007-10012. https://doi.org/10.1021/ac9018507.

Wulandari, R., Ivandini, T. A., Irkham, Saepudin, E., \& Einaga, Y. (2019). Modification of boron-doped diamond electrodes with platinum to increase the stability and sensitivity of haemoglobin-based acrylamide sensors. Sensors and Materials, 31(4), 1105-1117. https://doi.org/10.18494/SAM.2019.2192. 